\title{
The impact of Pinus halepensis afforestation on Mediterranean sponta- neous vegetation: do soil treatment and canopy cover matter?
}

\author{
Pasta Salvatore • Tommaso La Mantia • Juliane Rühl
}

Received: 2011-10-06; Accepted: 2011-12-14

(C) Northeast Forestry University and Springer-Verlag Berlin Heidelberg 2012

\begin{abstract}
We investigated central Mediterranean Pinus halepensis plantations under semi-arid climate in order to evaluate the combined effect of soil treatment and afforestation practices on spontaneous plant species composition, richness and evenness, and on the trend and speed of vegetation dynamics. Phytosociological relevés of three different plot typologies, i.e. (1) soil-treatment and plantation, (2) only soil-treatment, (3) no soil-treatment and no plantation, were compared by (a) multivariate analysis and (b) with reference to species richness and evenness. Moreover, in order to compare vegetation dynamics within the plantations with those ones ongoing in semi-natural garrigue communities, we compared life form and syntaxonomic spectra between phytosociological relevés taken at 8 years of distance. DCA showed that floristic species composition and similarity are influenced by the canopy cover of Pine trees as well as by soil-treatment practices. Although species richness and evenness are not clearly related to neither soil treatment nor Pine afforestation, canopy cover clearly plays a major role: in fact, the highest $\mathrm{Ph}$ cover rates correspond to the lowest values of understory species richness. This is true also if only species of biogeographical/conservation interest are considered. Regarding vegetation dynamics, sites with dense Pine canopy cover evolve much slower than the adjacent garrigue communities. The same factors invoqued to explain the patterns of floristic composition and similarity (i.e. allelopathy and competition for light, water and nutrients) may also explain the lowering of diversity of therophytes and the strong decline of the cover perfomed by both therophytes and hemicryptophytes underneath the canopy of dense $\mathrm{Ph}$ plantations. Thus, in sites where $P h$ cover exceeds about $80 \%$, thinning is recommended not only in order to accelerate succession, but also to give a natural 'shape' to afforestations.
\end{abstract}

Keywords: plant diversity; understory; vegetation dynamics; plantation

The online version is available at http://www.springerlink.com

Pasta Salvatore • Tommaso La Mantia (- Juliane Rühl

Dipartimento DEMETRA, Università di Palermo, Viale delle Scienze, Ed. 4, Ingr H, 90128 Palermo, Italy. Tel.: +39 091 7049040; fax: +39 091 7049025, E-mail address: tommaso.lamantia@unipa.it

Responsible editor: Chai Ruihai

\section{Introduction}

In the 20th century, large surfaces of the Mediterranean arid and semi-arid areas of the world have been afforested with Pinus halepensis Mill. (hereinafter $P h$ ). These plantations were designed to fulfill a multiplicity of objectives like habitat protection, increase of forest cover, etc. (Ne'eman and Trabaud, 2000). In fact, $P h$ afforestations have been considered very effective against the deterioration of grasslands and garrigues, so they were mainly carried out in strongly disturbed and/or degraded sites where spontaneous progressive succession appeared to be very slow (Alrababah et al. 2007).

In this context, a crucial point with $P h$ afforestations is if they are able to evolve towards 'final' Mediterranean communities or not by favouring the shrubs and trees typical to the final steps of succession. Despite the opinion of some authors (e.g. Gil and Aránzazu Prada, 1993), indeed $P h$ plantations do not always show a positive or neutral role in that regard. As for the short to the medium term (i.e. within 3-15 years after planting), several recent studies suggest that $P h$ afforestations may significantly improve the environmental quality of degraded areas when substituting very scattered herbaceous or subshrub communities (Le Houérou, 2000). For example, positive trends concerning various indicators (e.g. number of plant species, total plant cover, perennial species density, soil evolution, etc.) have been recorded by Grünzweig et al. (2007) and by Jeddi and Chaieb (2010).

But if we consider longer time lapses the results are not so univocal. Several studies in the western Mediterranean Basin (e.g. Chiarucci and De Dominicis, 1995; Andrés and Ojeda, 2002) have shown that planted pine woodlands have a negative impact on the diversity of the local flora. For example, Alrababah et al. (2007) found a lower number of species with increasing $P h$ cover in a semi-arid Mediterranean area.

In addition to tree cover, also soil treatments (such as subsoiling and terracing) and silvicultural treatments (such as removal of native shrubby vegetation) could have effects on the biodiversity within $P h$ plantations, but up to now only few relevant stud- 
ies have been published on the impacts of these treatments on plant diversity (e.g. Chirino et al. 2006; Fernández et al. 2010; Prévosto et al. 2011).

On the other hand, elsewhere in central Mediterranean (Liguria: Moreno et al. 1993; central Sardinia: Bianchi et al. 2002) it has been observed that artificial pine woods may enhance both succession and biodiversity if (1) they are not too dense, (2) the autochthonous species typical to the last stages of succession are favoured by shading (e.g.: Quercus ilex), and (3) local climatic conditions are more humid (i.e. mesomediterranean or supramediterranean)

Nowadays plantation forestry practice is under profound review worldwide (Harrington, 1999). In fact, developing the ideas of some pioneer papers on this topic (e.g. Noy-Meir, 1989), recent forest planning and management policies are ecologicallyoriented. Such new addresses are even more important within semi-arid contexts (e.g. Israel: Ginsberg, 2006) and they represent a trial to apply European-wide recommendations to the Mediterranean environment (FAO, 2006; Fabbio et al. 2003).

In Italy, only recently attention has been paid on the need of re-addressing $P h$ plantations management according to modern sustainable silviculture practices, especially within protected areas. Although their effectiveness is still under lively debate, in Italy the removal of native shrubby vegetation, the mechanical terracing before strip planting or subsoiling still represent the most common soil-treatment steps preceding afforestation (Garfi et al. 2002). Instead of applying the same soil treatment as a standard, modern afforestation should use variable soil treatment practices, selected in agreement with local pedo-climatic conditions, past land use and afforestation purposes (Corona et al. 2009).

In addition to the former issues, the conservation of biodiversity of open semi-natural ecosystems is one of the priority goals of the EU environmental policy because of their high rates of species richness and species of biogeographic/conservation interest (Peco et al. 1983). Therefore, considering the need to preserve Mediterranean open semi-natural ecosystems and the ongoing debate on pre-afforestation soil treatments, our paper aims at answering the first research question: (1) do soil treatment practices and tree cover of $P h$ afforestations affect species composition and plant diversity patterns (species richness and evenness) of Mediterranean semi-natural communities?

Moreover, in order to verify if and to what extent $P h$ plantations could affect the restoring of natural semi-arid woody ecosystems by counteracting degradation, in the present paper we compared the vegetation dynamics of $P h$ plantations and garrigues. Our hypothesis was that $P h$ plantations are in a steady state and that without any silvicultural intervention (e.g. thinning) they stop local progressive succession process which should lead to its gradual substitution by autochthonous woody communities. So, our second research question is: (2) which are the vegetation dynamics within $P h$ afforestations as compared to semi-natural (garrigue) communities?

The answers to these two questions may help resource managers and decision makers to outline effective plans to better conserve, manage and restore semi-natural Mediterranean ecosys- tems under semi-arid bioclimatic conditions.

\section{Materials and methods}

Site description

\section{Geography, geo-pedology and climate}

Data sampling was done in the central Mediterranean island of Lampedusa (Fig. 1), which is part of the Pelagie Archipelago and is located in Sicily Strait (35'30' N; $12^{\circ} 36^{\prime}$ E; ca. $20 \mathrm{Km}^{2}$ surface). It is characterized by gentle slopes interrupted by narrow canyons; its maximum height is $133 \mathrm{~m}$ a.s.l. The most common rock outcrops are limestones and marls (Grasso and Pedley, 1988).

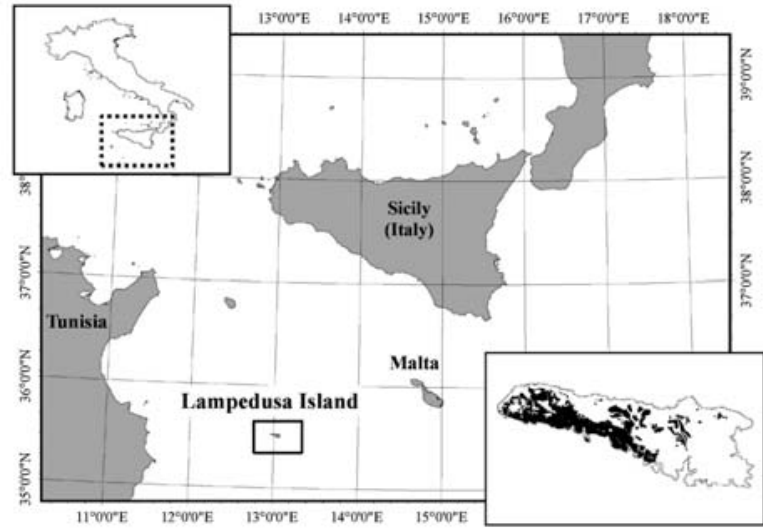

Fig. 1 Location of Lampedusa within central Mediterranean area. Upper left corner: position of Sicily within Italian territory; lower right corner: distribution of afforested areas (black) and garrigues (grey) on the island.

Local soils are characterised by the association Lithic Xerorthents - Rock outcrop - Typic elo Lithic Haploxerepts. These poorly evolved soils show an 'A-R' profile, whose upper horizon is only slightly differentiated. The horizon $\mathrm{A}$ is rather thin (average depth c. $15 \mathrm{~cm}$ ) with abundant skeleton and low organic matter content.

Local climate is classified as inframediterranean uppersemiarid according to that of Rivas-Martínez (2008). Average yearly temperature is about $19^{\circ} \mathrm{C}$, the coldest month is February $\left(9-14^{\circ} \mathrm{C}\right.$, never under $\left.2^{\circ} \mathrm{C}\right)$, while the hottest one is August $(24-$ $30^{\circ} \mathrm{C}$, sometimes nearly $35^{\circ} \mathrm{C}$ ). Although extremely irregular, precipitations show a typically Mediterranean regime: in fact, they are mostly concentrated between october and march. During the last 150 years mean annual rainfall decreased from $500 \mathrm{~mm}$ to $300 \mathrm{~mm}$; moreover, present average monthly values rarely exceed $60 \mathrm{~mm}$, while drought period may last more than six months (La Mantia et al. 2011). Besides rain and overnight dew accumulation, wind regime is the third driving force of local climate. In fact, windy days are $80 \%$ per year (Chamard et al. 1998). 


\section{Vascular flora and vegetation}

Because of their exceptional interest, local vascular flora and vegetation have been thoroughly and regularly investigated since Gussone (1839) till recent times (La Mantia et al. 2009): Lampedusa hosts 11 strictly endemic plants and the only Italian populations of many species with S Mediterranean, MediterraneanSaharian and Mediterranean-Irano-Turanian distribution, which testify the repeated connections of the island with $\mathrm{N}$ Africa during Pleistocene. Many of these noteworthy taxa are threatened at national and regional level (Conti et al. 1997).

The history of Lampedusa's landscape is emblematic of the disruptive effect of human pressure on Mediterranean island ecosystems. In fact, during the last 170 years pre-forest and forest communities - once covering most part of the island - have been erased (Pasta and La Mantia, 2004), and today native pine communities with Aleppo pine have totally disappeared; very few and scattered spots of thermophilous maquis (alliance OleoCeratonion siliquae) have survived and even local garrigue communities (alliance Cisto-Ericion multiflorae) are degraded and species-poor with respect to past times. The extreme rarity of pre-forest and forest vegetation spots heavily biases local progressive succession processes, which since about two decades are in progress in many parts of the island due to the strong reduction of grazing activities. In fact, the results of 12 years of floristic and structural investigations carried out in a permanent plot within a garrigue undergoing post-grazing succession testify the low speed of local progressive succession.

At present the most widespread woody plant community is a species-poor garrigue assemblage with Thymbra capitata, Jasonia lopadusana, Lotus cytisoides, Phagnalon rupestre, etc.. Rather common are also perennial grasslands dominated by Hyparrhenia and/or Piptatherum spp. (all. Hyparrhenion hirtae) and ephemeral annual prairies ascribed to the class StipoTrachynietea distachyae, very rich in species of high biogeographical interest. Due to local stress factors (summer drought, wind regime, etc.) and past disturbance (overgrazing after deforestation), even xeric grasslands are often substituted by an assemblage dominated by two poisonous stress-tolerant geophytes, Charybdis maritima and Asphodelus ramosus.

\section{Soil treatment and afforestation practices}

In order to restore succession processes and to stop soil erosion due to wind and extreme rainfall events, local afforestation activities were carried out on the above-mentioned degraded preforest communities. An overall surface of about 218 ha, i.e. nearly $10.8 \%$ of the whole island, has been afforested from 1967 to 1994 (Pasta and La Mantia, 2001). After some first unsuccessful experiences without soil treatments, from the late 1960s onwards subsoiling was carried out as a preliminary soil treatment before $P h$ planting, in order to crush and remove the outcropping rocks and to open furrows deep enough to allow the planting of the young trees with their root balls and to improve soil drainage. Unfortunately, these practices increased evapotranspiration, too. Moreover, young $P h$ trees were protected from wind through dry-stone walls. No thinning or pruning has been applied during the decades following plantation.
Today, most of the $P h$ plantations on Lampedusa differ largely in tree cover and density due to their uneven success rate.

\section{Data sampling}

In total, 16 sample plots differing in (1) preliminary soiltreatment and (2) $P h$ canopy cover were selected (see Table 1 for main characteristics). In six of these sites, $P h$ plantations have been carried out between 1967 and 1986, with preliminary subsoiling (hereinafter $P h$-plots). In other 4 sites, subsoiling had been carried out as a preliminary treatment for afforestation, but no $P h$ plantation was ever realised (hereinafter $S T$-plots, as soil treatment). The remaining 6 sites are represented by natural garrigue communities (hereinafter $G$-plots, as garrigue), where neither $P h$ plantation nor subsoiling have ever been performed. Prior to subsoiling, $P h$ - as well as $S T$-sites hosted garrigue communities mixed with ephemeral and perennial grasslands degraded by sheep and goat grazing. $G$-plots shared the same plant communities up to 15 years ago, when grazing was abandoned in the sampled areas.

All sampling sites share the same aspect, soil bedrock, and a very similar altitude and slope. None of them has been influenced by recent (i.e. less than 10 years) management or disturbance events (e.g. grazing, slashing, fire).

In 2009, phytosociological relevés (Braun-Blanquet, 1932) on $100 \mathrm{~m}^{2}$ surfaces were performed in each sample site. Relative abundance (cover) of plant species in each (tree, shrub and herbaceous) layer was recorded. Vascular plants were classified according to Tutin et al. (1964-1980, 1993) and Pignatti (1982), while their nomenclatural treatment mainly followed the checklist of Conti et al. (2005). The nomenclature of the considered phytosociological classes followed Rivas-Martínez et al. (1999).

In order to evaluate vegetation dynamics, in two $P h$-plots and in one $G$-plot, phytosociological relevés were performed in 2002 and in 2010 , respectively.

\section{Data analysis}

Species cover values of all phytosociological relevés were transformed following van der Maarel (1979). All data analyses refer to spontaneous vegetation; thus, $P h$ was deleted from the data set. All raw data used for data evaluation, including life forms (Raunkiær, 1934) and chorotypes, are reported in Appendix I.

\section{Floristic composition and similarity}

Multivariate analysis was used to identify environmental factors accounting for most of the variance within vegetation data. A data set including the 16 relevés carried out during 2009 was analysed with DCA, using CANOCO 4.0 (ter Braak and Smilauer, 2002). Downweighting of rare species was applied. The resulting axes were subsequently correlated to (1) percentage canopy cover of planted $P h$ trees, and (2) presence of soiltreatment.

\section{Richness and evenness}

Species richness and evenness $\left(E^{\prime}\right)$ were calculated for every 
sample plot. In order to calculate $E^{\prime}$ the formula proposed by Camargo (1993) was used. The use of $E$ ' provides two important advantages: 1) it does not rely on species richness and is relatively unaffected by the rare species present within the sample (Krebs, 1999), and 2) it has a value varying between 0.0 (species abundance significantly differs) to 1.0 (all species show the same abundance in a sample).

Moreover, in order to analyse the interaction between preliminary soil treatment and presence of $P h$ plantations, we used twoway ANOVA to compare the two levels of soil-treatment (applied vs not applied) and the two ones related to afforestation (done vs not done) with respect to the a) species richness and b) evenness.

Finally, the percentage cover of $P h$ trees was regressed against species richness. All statistical tests were computed with SigmaStat 3.0.

\section{Endemic and threatened species}

In order to evaluate the effect of plantations on the species of biogeographical/conservation interest, we checked the presence and frequence of both the endemic and the threatened species figuring within the red lists of Italian regions compiled by Conti et al. (1997) according to IUCN criteria.

Vegetation dynamics

In order to analyse vegetation dynamics in the afforested area and semi-natural garrigue communities, we calculated both the life form and the syntaxonomic spectra (i.e. the ratio of species belonging to different classes of vegetation) for the two $\mathrm{Ph}$ sample plots and the one $G$-sample plot, where relevés had been taken in 2002 and 2010, respectively. Separate analyses took into account (1) the number of species, and (2) their cover values (= weighted spectra). We also checked for any important variation in total species number within each of the selected plots.

\section{Results}

Floristic composition and similarity

Eigenvalues of the first two axes of DCA are 0.672 and 0.362 ; total inertia is 3.8 . Species axis 1 is well correlated with both the presence of soil-treatment practices (correlation coefficient $r=$ $0.57)$ and the percentage cover of planted $P h$ trees $(r=0.52)$. Also species axis 2 is correlated with the presence of soiltreatment practices $(r=0.63)$.

In the sample/environmental data biplot (Fig. 2), $P h$-samples mainly cluster in the lower left and $G$-samples in the upper right. The $P h$-samples with the highest canopy cover values (about $80 \%)$ are found more on the left ( $P h 1$ and $P h 5)$, while the ones with lower cover are found more on the right $(P h 2, P h 3, P h 4$ and $P h$ 6). So, the percentage of canopy cover of planted Pines seems to have an impact on spontaneous plant species composition. The few species common to all investigated $P h$ plots, which perform significant cover rates, are Asparagus acutifolius, Charybdis maritima, Asphodelus ramosus and Oxalis pes-caprae.
Also soil treatment has an impact on spontaneous vegetation composition, even if $S T$-plots do not form a unique cluster. Interestingly, the sites $S T 2$ and $S T$ 3, which are dominated by Phagnalon rupestre and Trachynia distachya, cluster with $P h$ plots of low Pine canopy cover, while the sites $S T 1$ and $S T$, which are characterized by a high cover of Charybdis maritima, cluster with not-managed semi-natural plots $(G 2, G 3$ and $G 6)$.

$G$-plots form two clusters: sites in the first cluster $(G 1, G 4$ and $G 5$ ) share similar high cover values of both Thymbra capitata and Thymelaea hirsuta, while in the sites of the second cluster $(G 2, G 3$ and $G$ 6) Phagnalon saxatile and Asphodelus ramosus do prevail.

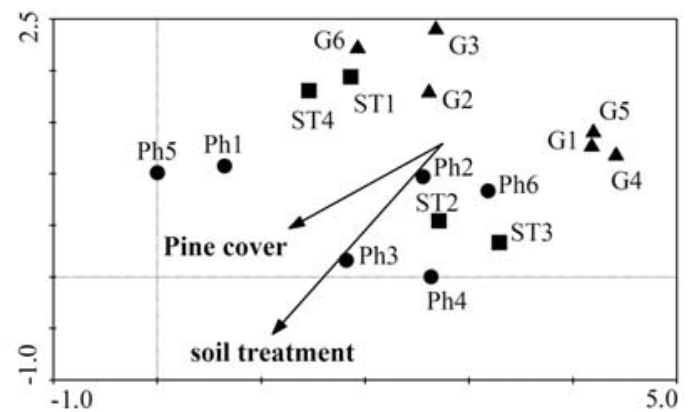

Fig. 2 DCA biplot of samples and environmental data (axes 1 and 2). Every relevé is represented by a symbol corresponding to its afforestation status: circles $=P h$-plots; squares $=S T$-plots; triangles $=G$-plots. The eigenvalue of axis 1 is 0.672 , while that of axis 2 is 0.362 .

\section{Richness and evenness}

Species richness is quite variable among the sample plots, and ranges from a minimum of 17 species in a $P h$ site to a maximum of 53 in a $G$ site (Table 1). Relative abundance of the species within the plots is quite uneven, as indicated by evenness values, ranging from 0.35 to 0.45 .

Two-way ANOVA (Table 2) puts in evidence that neither species richness nor evenness differed significantly between treatment groups. However, within the $P h$ treatment group, there is a trend of decreasing species richness with increasing Pine canopy cover $\left(\mathrm{R}^{2}=0.75\right.$; Fig. 3$)$. In fact, species-richness recorded within the densest afforestation plots are among the lowest of all the considered plots.

Endemic and threatened species

Table 3 lists the plants of biogeographical/conservation interest figuring within the field relevés. Interestingly, $P h$ afforestations with low Pine canopy cover (plots $P h 2, P h 3$ and $P h$ 4) host more plants of conservation interest than $G$-plots, while dense afforestation plots ( $P h 1$ and $P h 5)$ are the poorest ones with only one species, Thapsia pelagica.

Vegetation dynamics

Comparisons between two $\mathrm{Ph}$ afforestations and a garrigue community allowed to record clear differences in both life form 
and syntaxonomic spectra in the considered sites.

Table 1. Main characteristics, species richness (SR), evenness $\left(E^{\prime}\right)$ and number of taxa of conservation interest (TCI) according to Conti et al. (1997) of the plots sampled in 2009.

\begin{tabular}{|c|c|c|c|c|c|c|c|c|c|c|c|c|}
\hline Plot & ST & aff & $\begin{array}{c}\text { Pine } \\
\% \\
\end{array}$ & $\begin{array}{c}\text { Shrub } \\
\% \\
\end{array}$ & $\begin{array}{c}\text { Herb } \\
\% \\
\end{array}$ & $\begin{array}{c}\text { Rock } \\
\% \\
\end{array}$ & $\begin{array}{c}\text { Stone } \\
\% \\
\end{array}$ & $\begin{array}{c}\text { Pine } \\
\mathrm{cm}\end{array}$ & $\begin{array}{c}\text { Shrub } \\
\mathrm{cm}\end{array}$ & SR & $E^{\prime}$ & TCI \\
\hline$P h 1$ & yes & yes & 95 & 4 & 10 & 5 & 10 & 360 & 80 & 17 & 0.381 & 1 \\
\hline$P h 2$ & yes & yes & 70 & 4 & 20 & 5 & 30 & 250 & 50 & 42 & 0.499 & 9 \\
\hline$P h 3$ & yes & yes & 20 & 4 & 30 & 5 & 40 & 150 & 60 & 40 & 0.444 & 6 \\
\hline$P h 4$ & yes & yes & 1 & 10 & 50 & 5 & 30 & 130 & 60 & 42 & 0.329 & 10 \\
\hline$P h 5$ & yes & yes & 80 & 4 & 70 & 10 & 20 & 300 & 50 & 26 & 0.204 & 1 \\
\hline$P h 6$ & yes & yes & 75 & 25 & 50 & 15 & 40 & 230 & 50 & 22 & 0.354 & 3 \\
\hline$S T 1$ & yes & no & - & 15 & 65 & 10 & 40 & - & 35 & 46 & 0.363 & 5 \\
\hline$S T 2$ & yes & no & - & 20 & 30 & 0 & 50 & - & 30 & 37 & 0.349 & 8 \\
\hline ST 3 & yes & no & - & 1 & 75 & 10 & 40 & - & 50 & 18 & 0.177 & 3 \\
\hline ST 4 & yes & no & - & 10 & 70 & 20 & 30 & - & 40 & 46 & 0.350 & 7 \\
\hline$G 1$ & no & no & - & 40 & 50 & 10 & 10 & - & 25 & 25 & 0.419 & 6 \\
\hline$G 2$ & no & no & - & 60 & 40 & 10 & 40 & - & 40 & 39 & 0.211 & 9 \\
\hline$G 3$ & no & no & - & 50 & 40 & 5 & 30 & - & 40 & 49 & 0.312 & 7 \\
\hline$G 4$ & no & no & - & 45 & 25 & 15 & 25 & - & 50 & 22 & 0.380 & 8 \\
\hline$G 5$ & no & no & - & 55 & 25 & 0 & 15 & - & 15 & 26 & 0.264 & 3 \\
\hline$G 6$ & no & no & - & 30 & 45 & 5 & 35 & - & 60 & 53 & 0.417 & 5 \\
\hline
\end{tabular}

ST $=$ soil-treatment; aff $=$ Pine afforestation; Pine $\%=$ percentage canopy cover of $P h$ trees; shrub $\%=$ percentage cover of spontaneous shrubs; herb \% $=$ percentage cover of spontaneous herbs; rock $\%=$ percentage cover of rock outcrop; stone $\%=$ percentage cover of stones; Pine $\mathrm{cm}=$ mean height of $\mathrm{Ph}$ tree layer; shrub $\mathrm{cm}=$ mean height of shrub layer.

Table 2. Results of two-way ANOVA.

\begin{tabular}{lrrrc}
\hline Source of variation & DF & MS & F & P \\
\hline Richness & & & & \\
Soil treatment & 1 & 2.817 & 0.018 & 0.895 \\
Pine cover & 1 & 66.150 & 0.424 & 0.526 \\
Residual & 13 & 156.122 & & \\
Evenness & & & & \\
Soil treatment & 1 & 0.00139 & 0.161 & 0.690 \\
Pine cover & 1 & 0.00828 & 0.961 & 0.350 \\
Residual & 13 & 0.00862 & & \\
\hline
\end{tabular}

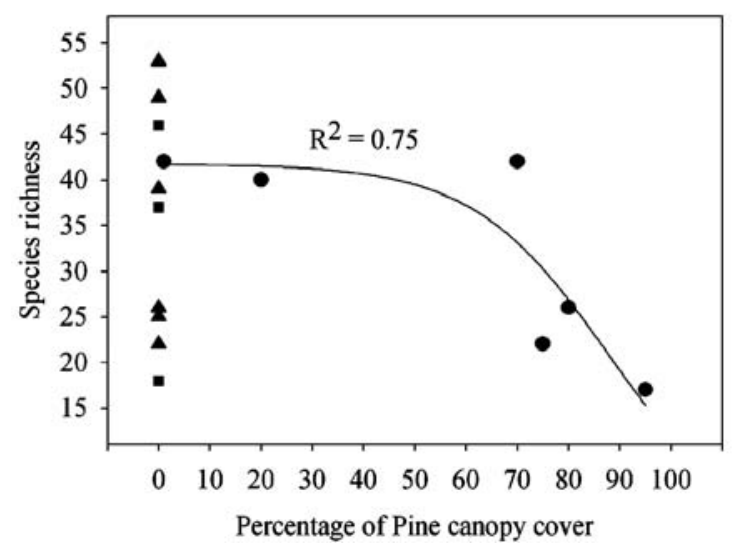

Fig. 3 Species richness along percentage canopy cover of $\boldsymbol{P h}$. Circles $=P h$-plots; squares $=S T$-plots; triangles $=G$-plots.
Table 3. List of the plants of biogeographical/conservation interest figuring within the field relevés (see also Appendix I).

\begin{tabular}{|c|c|c|}
\hline Taxon & Chorotype & IUCN \\
\hline Anthemis lopadusana Lojac. & End Lampedusa & $\mathrm{EN}$ \\
\hline $\begin{array}{l}\text { Caralluma europaea (Guss.) N.E.Br. subsp. } \\
\text { europaea }\end{array}$ & SW Medit & $\mathrm{CR}$ \\
\hline Carlina involucrata Poir. & SW Medit & VU \\
\hline Crucianella rupestris Guss. & SE Medit & VU \\
\hline Cuscuta palaestina Boiss. & SE Medit & LR \\
\hline Daucus lopadusanus Tineo & End Lampedusa & VU \\
\hline Daucus siculus Tineo & End S Italy \& Sicily & LR \\
\hline Diplotaxis scaposa DC. & End Lampedusa & LR \\
\hline $\begin{array}{l}\text { Euphorbia pycnophylla (K.U.Kramer \& We- } \\
\text { stra) C.Brullo \& Brullo }\end{array}$ & End Lampedusa & VU \\
\hline Filago gussonei Lojac. & End S Italy \& Sicily & LR \\
\hline $\begin{array}{l}\text { Hypericum aegypticum L. subsp. webbii } \\
\text { (Spach) N.K.B.Robson }\end{array}$ & S Medit & $\mathrm{EN}$ \\
\hline $\begin{array}{l}\text { Jasonia lopadusana (Brullo) Pardo de } \\
\text { Santayana \& Morales }\end{array}$ & End Lampedusa & VU \\
\hline Lagurus ovatus L. subsp. nanus & CW Medit & VU \\
\hline Limonium lopadusanum Brullo & End Pelagie & LR \\
\hline $\begin{array}{l}\text { Linaria reflexa (L.) Desf. subsp. lubbockii } \\
\text { (Batt.) Brullo }\end{array}$ & S Medit & VU \\
\hline Lycium intricatum Boiss. & S Medit & DD \\
\hline Ophrys ciliata Biv. & Medit & LR \\
\hline Periploca angustifolia Labill. & S Medit-Sahar & LR \\
\hline $\begin{array}{l}\text { Plantago afra L. subsp. zwierleinii (Nicotra) } \\
\text { Brullo }\end{array}$ & End Sicily & LR \\
\hline Reichardia tingitana (L.) Roth & Tetid & LR \\
\hline $\begin{array}{l}\text { Thapsia pelagica Brullo, Guglielmo, Pasta, } \\
\text { Pavone \& Salmeri }^{1}\end{array}$ & End Lampedusa & - \\
\hline
\end{tabular}

${ }^{1}$ No risk level figures in Conti et al. (1997) because this species has been described afterwards.

End $=$ endemic; $\mathrm{CR}=$ critically endangered, $\mathrm{EN}=$ endangered, $\mathrm{VU}=$ vulnerable, $\mathrm{LR}=$ subject to low risk, $\mathrm{DD}=$ data deficient.

As concerns life form, from 2002 to 2010 a strong decrease of frequency of therophytes $(\mathrm{T})$, coupled to a slight reduction of hemicryptophytes (H) occurred within $P h$-sites (Fig. 4). On the contrary, geophytes $(\mathrm{G})$, chamaephytes $(\mathrm{Ch})$ and phanerophytes (P) increased, while no nano-phanerophytes (NP) colonized the plots. In contrast, in the $G$-site a slight reduction of T and a small increase of $\mathrm{H}$ and NP have been recorded, while the other life forms did not experience any significant variation.

When cover pattern is considered, the life-form spectrum of $P h$-sites (Fig. 5) shows the same trend as for "number", underlining the major role played by $\mathrm{G}(70-90 \%)$ and the dramatic reduction of T from 2002 to 2010 . Only Ch show irregular changements, as they increase in $P h 1$ and diminish in $P h$ 5. In the $G$ site, $\mathrm{T}$ and $\mathrm{H}$ experienced some reduction as well as $\mathrm{G}$ $(50 \rightarrow 30 \%)$, while woody plants $(\mathrm{Ch}, \mathrm{NP}+\mathrm{P})$ increased. 


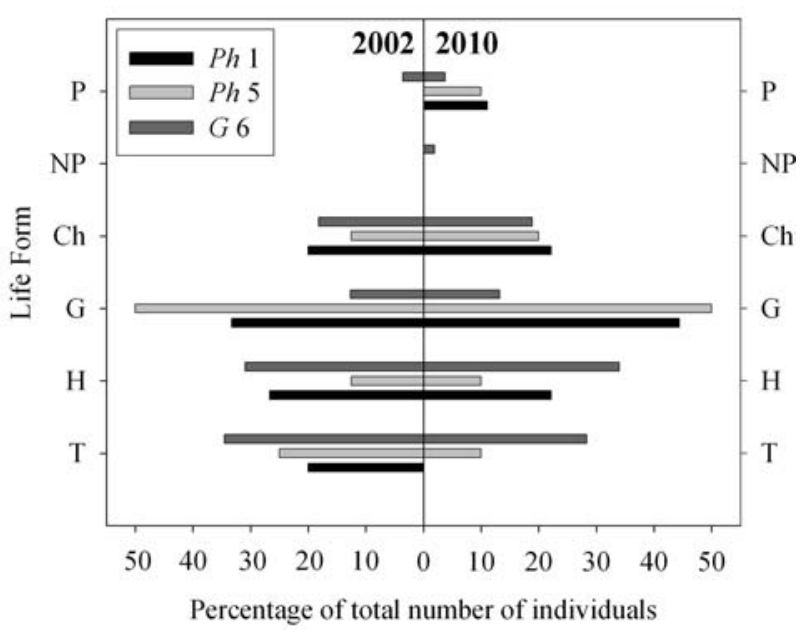

Fig. 4 Changes in number values of life-forms from 2002 to 2010. See Table 1 for plot codes. Life-form abbreviations (Raunkiær, 1934): $\mathrm{T}=$ Therophytes; $\mathrm{H}=$ Hemicryptophytes; $\mathrm{G}=$ Geophytes; $\mathrm{Ch}=$ Chamaephytes; $\mathrm{NP}=$ Nano-Phanerophytes; $\mathrm{P}=$ Phanerophytes.

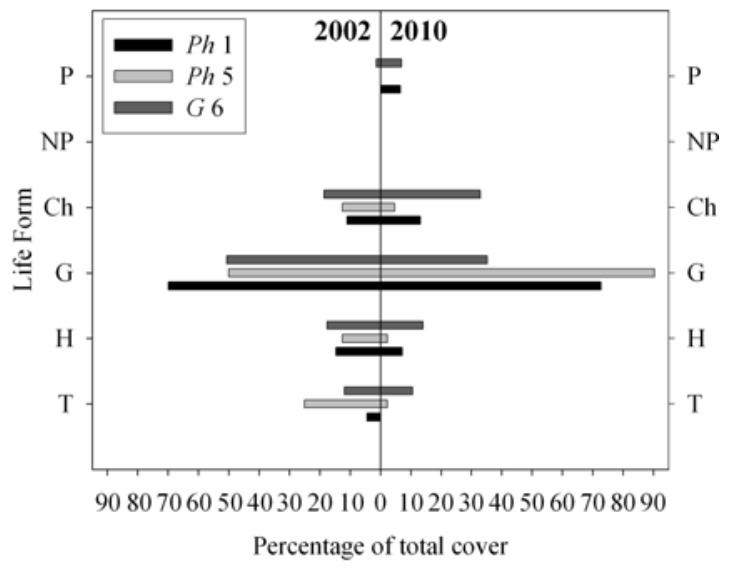

Fig. 5 Changes in cover values of life-forms from 2002 to 2010. Abbreviations as indicated in Fig. 4.

Regarding the number of individuals of each phytosociological class (Fig. 6), in Ph-sites Quercetea ilicis characteristic species increased from 2002 to 2010, while those linked to Stellarietea mediae and Stipo-Trachynietea distachyae decreased. Considering the perennial herbs linked to Lygeo-Stipetea, they increased in $P h 1$ and decreased in $P h$ 5. Within the $G$-site $L y$ geo-Stipetea, Stipo-Trachynietea distachyae and CrithmoLimonietea increase, the annual species linked to Stellarietea mediae decrease and the species characteristic of Quercetea ilicis do not change.

Changes in term of cover rate (Fig. 7), are quite different in comparison to individual numbers: within $P h$-sites, LygeoStipetea species nearly disappear and those of StipoTrachynietea distachyae decrease, while Stellarietea mediae ones increase. The evolution of Quercetea ilicis species is rather uncertain, as they increase in $P h 1$ and decrease in $P h$ 5. The $G$ site is characterized by a significant decrease of CistoMicromerietea subshrubs, while those of Stellarietea mediae and Lygeo-Stipetea ones perform a slightly lower cover. Interestingly, Quercetea ilicis species experience a very strong increase, while the increase of those referred to Stipo-Trachynietea distachyae is less important.

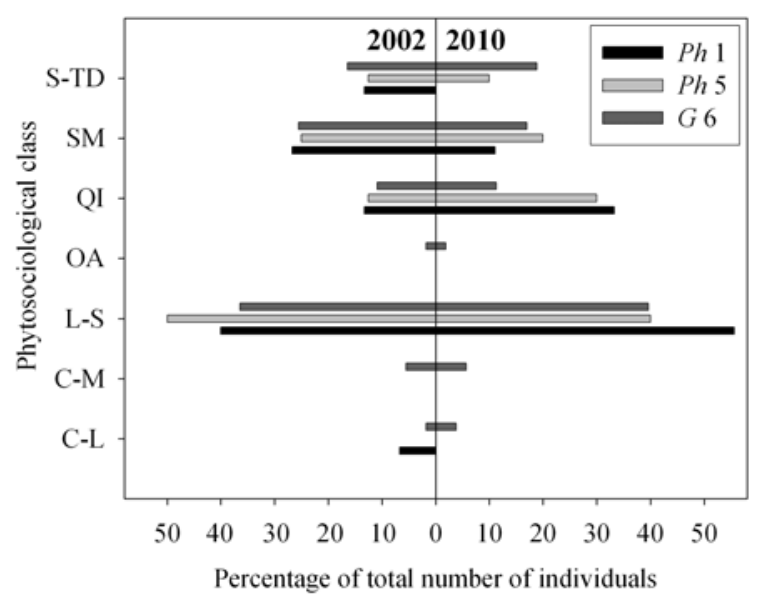

Fig. 6 Changes in number values of phytosociological classes from 2002 to 2010. See Table 1 for plot codes. Phytosociological class abbreviations: $\mathrm{C}-\mathrm{L}=$ Crithmo-Limonietea $; \mathrm{C}-\mathrm{M}=$ Cisto-Micromerietea $; \mathrm{L}-\mathrm{S}$ : Lygeo-Stipetea $; \mathrm{OA}=$ Onopordetea acanthii $; \mathrm{QI}=$ Quercetea ilicis; $\mathrm{SM}$ = Stellarietea mediae; S-TD = Stipo-Trachynietea distachyae. Data concerning the classes Papaveretea rhoeadis, Pegano-Salsoletea and Saginetea maritimae were omitted because they reach very low values in all the considered plots.

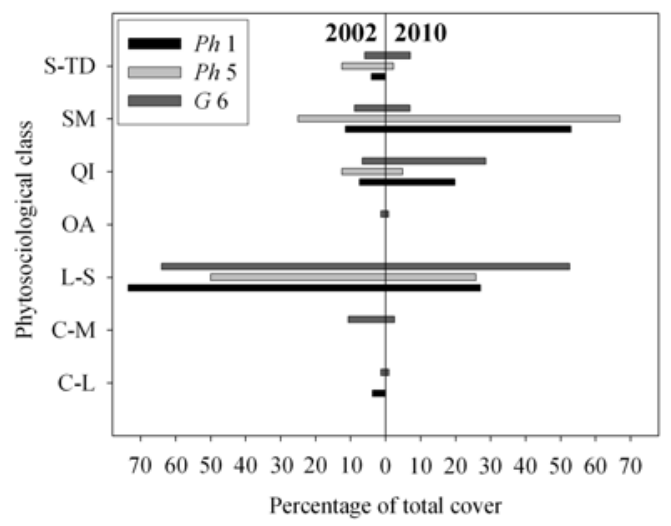

Fig. 7 Changes in cover values of phytosociological classes from 2002 to 2010. Abbreviations as indicated in Fig. 6.

In synthesis, afforestation sites with dense Pine canopy cover are not in a steady state, but are subject to vegetation dynamics. However, these dynamics are different from the ones in seminatural garrigue, and, in terms of renaturation (i.e. increase of spontaneous woody species cover) they are much slower. Even if in $P h$ sites we registered a frequency increase of woody species, their cover on the contrary did not increase significantly, while

\section{Springer}


geophytes gained much importance. In contrast, the garrigue community is steady in woody species' numbers, but gains much woody cover of species referred to Quercetea ilicis, which should be the final stage of progressive succession at Lampedusa.

\section{Discussion}

Floristic composition and similarity

Floristic species composition is influenced by the canopy cover of Pine trees as well as by soil-treatment practices. Too dense $P h$ plantations may inhibit understorey colonization by plants due to excessive shading and to litter accumulation. In fact, high $P h$ cover gives rise to a thick ' $\mathrm{O}$ ' horizon made by undecomposed needles that hampers the establishment of native woody species (Navarro-Cano et al. 2009), has a strong allelopathic effect (Nektarios et al. 2005; Fernandez et al. 2006) and may reduce water infiltration through the soil by capturing the few water supply given by the rare rainfalls, as it has been observed also for other Pinus species by Shi and Gu (2007).

Preliminary soil-treatments may increase the average depth of available soil, but often promote soil erosion, alter water regime, induce microhabitat loss and nutrient depletion, thus biasing spontaneous seedling establishment (Maestre et al. 2007). Moreover, as already observed elsewhere in Mediterranean area (Puerto and Rico, 1997), the effects of these factors very likely overlap with fluctuations in soil depth, soil stoniness, microtopography and differences in the initial floristic composition at plot level.

In some sample plots (ST 1 and ST 4) in which subsoiling was carried out without subsequent afforestation, we found a high cover rate of Charybdis maritima. From a floristic point of view these sites are similar to some semi-natural $G$-sites where $A s$ phodelus ramosus and Phagnalon saxatile are very common. Charybdis and Asphodelus often coexist as they share the same ecological requirements and probably dominated these areas already before subsoiling; thus soil treatment practices seem to not significantly affect the pre-existent vegetation pattern. Moreover, it must be highlighted that plant communities dominated by Asphodelus ramosus and Charybdis maritima are considered as the last degradation stages of the Mediterranean ecosystems. Both species take advantage from their strong tolerance to edapho-climatic stress factors (Rhizopoulou et al. 1997; Grammatikopoulos et al. 1999) and their high resistance and resilience to disturbance factors such as grazing (Pantis and Mardiris, 1993), competition and burning.

In subsoiled and afforested sample plots, the difference in species composition between dense and open $P h$ plantations is striking. The $P h$-sites characterized by low Pine canopy cover show a similar floristic composition to those $S T$-sites which are dominated by Phagnalon rupestre and Trachynia distachya. To explain this pattern an edaphic explanation may be invoqued: in fact, both plants are helio-xerophilous pioneers, but Phagnalon rupestre prefers thin, sandy and/or stony soils, whereas Trachynia colonizes also rock crevices. Thus, we could argue that soil erosion due to subsoiling and/or to unsuccessful plantation biased any evolution of soil and vegetation within open and/or failed afforestations.

Richness and evenness

Species richness and evenness are not related to the execution of soil treatment nor to the presence/absence of Pine afforestation. However, in agreement with Alrababah et al. (2007), we noticed for the afforested sites that the denser $P h$ cover is, the lower is the number of species under its canopy. Richness decreases drastically when Pine cover exceeds $80 \%$, a pattern observed also in other southern Italian $\mathrm{Ph}$ plantations (Pignatti, 1993).

In these cases, the nearly continuous canopy and the thick litter which covers the ground act as a complex barrier by strengthening the effect of local limiting factors such as light, water and nutrients. Concerning light, already Battles et al. (2001) noticed that plots with more bare ground and lower tree coverage showed higher species richness. As for water, competition by $P h$ must be considered a major constraint for the survival of herbaceous species and the seedlings of the understorey (Bellot et al. 2004): in fact, Aleppo pines have relatively shallow root systems, with maximum density of fine roots occurring at less than $50 \mathrm{~cm}$ from soil surface (Canadell et al. 1999).

\section{Endemic and threatened species}

Also the biogeographic value of the flora observed within the $P h$-sites with high Pine cover is by far the lowest of all the considered plots, while the values of less dense Pine plantations are similar to the semi-natural garrigues. As most part of these noteworthy species are annual r-strategists (Grime, 2001), they are more common either in $G$-sites or in open $P h$ plantations, while they gradually succumb within too dense plantations because they are unable to compete with pines for nutrients, light and water.

\section{Vegetation dynamics}

Our initial hypothesis was partially contradicted: $P h$ afforestation sites are not in a steady state, as life form and phytosociological class spectra changed over the investigated time period. However, only a very slow renaturation process has been recorded within dense plantations, with a major increase in geophytes of Stellarietea mediae (i.e. Oxalis pes-caprae), and only slight increases in Quercetea ilicis woody species cover. The same factors invoqued to explain the patterns of floristic composition and similarity (i.e. allelopathy and competition for light, water and nutrients) may also explain the lowering of diversity of therophytes and the strong decline of the cover perfomed by both therophytes and hemicryptophytes underneath the canopy of dense $P h$ plantations. Thus, in sites where $P h$ cover exceeds about $80 \%$, thinning is recommended not only in order to accelerate succession, but also to give a natural 'shape' to afforestations.

As regards geophytes, the case of Oxalis pes-caprae worths 
some more details. While its presence has been recorded in all the investigated $P h$-sites and $S T$-sites (see Table 2), none of the $G$-sites hosts it. These data, together with the increase of its cover rate in both the $P h$-sites compared for the analysis of vegetation dynamics, suggest that the disturbance induced by soiltreatment has favoured its vegetative spread. Our hypothesis agrees with the most recent literature on the dispersal strategies and the ecological niche of this invasive alien species (Verdaguer et al. 2010).

Within its natural range, $P h$ is considered to disappear once the communities in which it lives start to evolve towards more closed tree-dominated communities (Bartolo et al. 1986; Paola et al. 1991). In contrast, when $P h$ is used for afforestation, no or very slow spontaneous transformation into sclerophyllous maquis or forests is recorded. $P h$ plantations may have negative effects on existing late-successional shrubs, i.e. chamaephytes + nano-phanerophytes + phanerophytes (Benabdeli, 1998; Bellot et al. 2004; Chirino et al. 2006). Maestre and Cortina (2004) argued that its introduction - albeit ameliorating understorey microclimatic conditions - is not able to facilitate the establishment of shrubs under semi-arid conditions.

\section{Concluding remarks}

Our study represents the first trial to evaluate the combined effect of soil treatment and afforestation practices on plant species-richness and evenness and on the speed of dynamic processes in a central Mediterranean semi-arid area. It confirms that in order to maintain biodiversity, not only conservation forest management practices, but also their total absence must be correctly planned. Optimal management strategies strongly depend on $P h$ cover rate. Dense $P h$ plantations should also be avoided where they may cause direct and indirect damages to protected plants and habitats of community interest according to 92/43 EU Directive.

Finally, regarding the spontaneous evolution of $P h$ plantations towards natural woody communities, future investigations should be focused on their influence on soil dynamics. In the context of global climate change, the transformation of $P h$ plantations to natural communities gains an important aspect, since recent studies show that in Mediterranean semi-arid ecosystems the organic carbon content is far lower on $P h$ plantations than in autochthonous pre-forest communities.

\section{Acknowledgements}

This research was funded by Regione Siciliana, Dipartimento Interventi Infrastrutturali, Area Studi e Programmazione. We are grateful to F. Guaitoli and G. Matranga for supporting the Project "Analisi dei sistemi seminaturali e degli agroecosistemi nei sistemi insulari mediterranei: Isola di Lampedusa e pantani di Vendicari”. We thank Legambiente, G. Nicolini and her staff, A. Dimarca, K. Sessa and the Regional Department of Forests for permissions and material help during field investigations. We also appreciated the revision of the final draft of the manuscript by G. Garfì and L. Gristina.

\section{References}

Alrababah MA, Alhamad MA, Suwaileh A, Al-Gharaibeh M. 2007. Biodiversity of semi-arid Mediterranean grasslands: impact of grazing and afforestation. Applied Vegetation Science, 1(2): 257-264.

Andrés C, Ojeda F. 2002. Effects of afforestation with pines on woody plant diversity of Mediterranean heathlands in southern Spain. Biodiversity \& Conservation, 11: 1511-1520.

Bartolo G, Brullo S, Minissale P, Spampinato G. 1986. Osservazioni fitosociologiche sulle pinete a Pinus halepensis Miller del bacino del fiume Tellaro (Sicilia sud-orientale). Bollettino dell'Accademia Gioenia di Scienze Naturali, s. 4, 18 (325)(1985): 255-270.

Battles JJ, Shlisky AJ, Barrett RH, Heald RC, Allen-Diaz BH. 2001. The effects of forest management on plant species diversity in a Sierran conifer forest. Forest Ecology and Management, 146: 211-222.

Bellot J, Maestre FT, Chirino E, Hernández N, de Urbina JO. 2004. Afforestation with Pinus halepensis reduces native shrub performance in a Mediterranean semiarid area. Acta Oecologica, 25(1-2): 7-15.

Benabdeli K. 1998. First dendrometrical results of Aleppo pine plantation (Pinus halepensis Mill.) in the Green Barrage (Aflou Algeria). Ecologia Mediterranea, 24: 43-51.

Bianchi L, Calamini G, Gregori E, Paci M, Pallanza S, Pierguidi A, Salbitano F, Tani A, Vedele S. 2002. Valutazione degli effetti del rimboschimento in zone aride della Sardegna: risultati preliminari sulla vegetazione. Italia Forestale e Montana, 57(4): 353-368.

Braun-Blanquet J. 1932. Plant sociology. New York-London: Mc Graw-Hill

Camargo JA. 1993. Must dominance increase with the number of subordinate species in competitive interactions? Journal of Theoretical Biology, 161: 537-542.

Canadell J, Djema A, López B, Lloret F, Sabaté S, Siscar D, Gracia CA. 1999. Structure and dynamic of the root system. In: Rodá, F., Retana, J., Gracia, C.A., Bellot, J. (Eds.), Ecology of Mediterranean Evergreen Oak Forests. Ecological Studies 137. Berlin-Heidelberg: Springer, pp. 47-59.

Chamard P, Ciattaglia L, Di Sarra A, Grigioni P, Monteleone F. Sarao R. 1998. The ENEA Station for climate observations at Lampedusa. RomaItaly: Conferenza Nazionale Energia e Ambiente, p.10.

Chiarucci A, De Dominicis V. 1995. Effects of pine plantations on ultramafic vegetation of central Italy. Israel Journal of Plant Sciences, 43: 7-20.

Chirino E, Bonet A, Bellot J, Sánchez JR., 2006. Effects of 30-year-old Aleppo pine plantations on runoff, soil erosion, and plant diversity in a semi-arid landscape in south eastern Spain. Catena, 65(1): 19-29.

Conti F, Abbate G, Alessandrini A, Blasi C. (eds.) 2005. An Annotated Checklist of the Italian Vascular Flora. Ministero dell'Ambiente e della Tutela del Territorio, Direzione per la Protezione della Natura. Palombi Ed., Roma, p.420.

Conti F, Manzi A, Pedrotti F. 1997. Liste Rosse Regionali delle Piante d'Italia. Camerino: W.W.F., Soc. Bot. Ital., p.139.

Corona P, Ferrari B, Iovino F, La Mantia T, Barbati A. 2009. Rimboschimenti e lotta alla desertificazione In Italia. Roma: Aracne Edritice, p.281.

Fabbio G, Merlo M, Tosi, V., 2003. Silvicultural management in maintaining biodiversity and resistance of forests in Europe - the Mediterranean region. Journal of Environmental Management, 67: 67-76.

FAO 2006. Planted Forests and Trees Working Paper FP37E. Responsible Management of Planted Forests, Voluntary Guidelines. Rome: FAO, United Nations.

Fernandez C, Lelong B, Vila B, Mévy J-P, Robles C, Greff S, Dupoyet S, Bousquet-Mélou A. 2006. Potential allelopathic effect of Pinus halepensis in the secondary succession: an experimental approach. Chemoecology, 16(2): 97-105. 
Fernández E, Rojo L, Jiménez MN, Navarro FB, Díez M, Martín F, Fernández J, Martínez J, Roca A, Aguilar J. 2010. Afforestation improves soil fertility in south-eastern Spain. European Journal of Forest Research, 194(4): $707-717$.

Garfî V, Iovino F, Menguzzato G, Nicolaci A. 2002. Preparazione del suolo e densità di impianto in rimboschimenti di pino d'Aleppo e di pino laricio: analisi e primi risultati. Italia Forestale e Montana, 57(4): 319-338.

Gil L, Aránzazu Prada M. 1993. Los pinos como especies básicas en la restauración forestal en el medio mediterráneo. Ecología, 7: 113-125.

Ginsberg P. 2006. Restoring biodiversity to pine afforestations in Israel. Journal for Nature Conservation, 14(3-4): 207-216.

Grammatikopoulos G, Petripoulou Y, Manetas Y. 1999. Site-dependent differences in transmittance and UV-B absorbing capacity of isolated leaf epidermis and mesophyll in Urginea maritima (L.) Baker. Journal of Experimental Botany, 50: 517-521.

Grasso M, Pedley HM. 1988. Carta Geologica dell'Isola di Lampedusa. Ministero della Pubblica Istruzione e Regione Sicilia, S.E.L.C.A. Firenze.

Grime JP. 2001. Plant Strategies, Vegetation processes and Ecosystem Properties, $2^{\text {nd }}$ ed., West Sussex: J. Wiley \& Sons.

Grünzweig JM, Gelfand I, Fried Y, Yakir D. 2007. Biogeochemical factors contributing to enhanced carbon storage following afforestation of a semiarid shrubland. Biogeosciences, 4: 891-904.

Gussone G. 1839. Notizie sulle isole di Linosa, Lampione e Lampedusa, e descrizione di una nuova specie di Stapelia che trovasi in questa ultima, lette nell'anno 1832. Atti della Reale Accademia delle Scienze, Sezione della Società Reale Borbonica, 4: 74-97.

Harrington CA. 1999. Forests planted for ecosystem restoration or conservation. New Forests, 17: 175-190.

Jeddi K, Chaieb M. 2010. Soil properties and plant community in different ages Pinus halepensis Mill. Plantations in arid Mediterranena areas: the case of southern Tunisia. Land Degradation \& Development, 21: 32-39.

Krebs CJ. 1999. Ecological Methodology, 2nd ed.. Menlo Park: Benjamin/Cummings, p.620.

La Mantia T, Carimi F, Di Lorenzo R, Pasta S. 2011. The agricultural heritage of Lampedusa (Pelagie Archipelago, South Italy) and its key role for cultivar and wildlife conservation. Italian Journal of Agronomy, 6(2): 106-110.

La Mantia T., Pasta S., Rühl J. 2009. Parte I - Fase conoscitiva - Flora e vegetazione, habitat comunitari, uso del suolo - del Piano di Gestione "Isole Pelagie", POR 1999.IT.16.1.PO.011/1.11/11.2.9/0304. Legambiente-Comitato Regionale Siciliano e Dipartimento di Colture Arboree dell'Università degli Studi di Palermo (http://www.artasicilia.eu/web/natura2000/index.html).

Le Houérou HN. 2000. Restoration and rehabilitation of arid and semiarid Mediterranean ecosystems in North Africa and West Asia: a review. Arid Soil Research and Rehabilitation, 14: 3-14.

Maestre FT, Cortina J. 2004. Are Pinus halepensis plantations useful as a restoration tool in semi-arid Mediterranean areas? Forest Ecology \& Management, 198(1-3): 303-317.

Maestre FT, Cortina J, Bautista S. 2007. Mechanisms underlying the interaction between Pinus halepensis and the native late-successional shrub Pistacia lentiscus in a semi-arid plantation. Ecography, 27(6): 776-786.

Moreno D, Croce GF, Guido MA, Montanari C., 1993. Cap. 7. Pine plantations on ancient grassland: ecological changes in the Mediterranean mountains of Liguria, Italy, during the 19th and 20th centuries. In: Watkins, C. (ed.), Ecological effects of afforestation. Studies in the history and ecology of afforestation in Western Europe. Oxford: CAB. International.

Navarro-Cano JA, Barberá GG, Ruiz-Navarro A, Castillo VM. 2009. Pine plantation bands limit seedling recruitment of a perennial grass under semiarid conditions. Journal of Arid Environments, 73: 120-126.

Ne'eman G, Trabaud L (eds.). 2000. Ecology, biogeography and management of Pinus halepensis and P. brutia forest ecosystems in the Mediterranean Basin. Leiden: Backhuys Publishers, p.407.
Nektarios PA, Economou G, Avgoulas C. 2005. Allelopathic effects of Pinus halepensis needles on turfgrasses and biosensor plants. Hortscience, 40(1): $246-250$.

Noy-Meir I. 1989. An ecological viewpoint on afforestation in Israel: past and future. Allgemeine Forst Zeitschrift, 24-26: 614-618.

Pantis JD, Mardiris TA. 1993. The effects of grazing and fire on degradation processes of Mediterranean ecosystems. Israel Journal of Botany, 41: 233-242.

Paola G, Barberis G, Peccenini S. 1991. Pinus halepensis formations in Liguria (NW Italy). Botaniká Chroniká, 10: 609-615.

Pasta S, La Mantia T. 2001. Note sul paesaggio vegetale delle isole minori circumsiciliane. I. Consorzi forestali e preforestali dell'isola di Lampedusa ed effetto degli impianti artificiali sulla vegetazione forestale. Il Naturalista siciliano, 25(suppl.): 71-89.

Pasta S, La Mantia T. 2004. Note sul paesaggio vegetale delle isole minori circumsiciliane. II. La vegetazione pre-forestale e forestale nelle isole del Canale di Sicilia. Annali dell'Accademia Italiana di Scienze Forestali, 52 [2003]: 77-124.

Peco B, Levassor C, Pineda F.D. 1983. Diversité et structure spatiale de pâturages méditerranéens en cours de succession. Ecol Medit, 9: 223-234.

Pignatti G. 1993. Diversità floristica in formazioni forestali artificiali mediterranee. Italia Forestale e Montana, 48(5): 272-283.

Pignatti S. 1982. Flora d'Italia. Bologna, Edagricole, 3 voll..

Prévosto B, Bousquet-Mélou A, Ripert C, Fernandez C. 2011. Effects of different site preparation treatments on species diversity, composition and plant traits in Pinus halepensis woodlands. Plant Ecology, 212(4): 627-638.

Puerto A, Rico M. 1997. Soil depth as determinant of structural trends in Mediterranean grasslands with abundant slaty outcrops. Ekológia, 16: 3-16.

Raunkiær C. 1934. The life-forms of plants and statistical plant geography. Oxford: Oxford University Press.

Rhizopoulou S, Pantis JD, Triantafylli E, Vokou D. 1997. Ecophysiological adaptations of Asphodelus aestivus to Mediterranean climate periodicity water relations and energetic status. Ecography, 20: 626-633.

Rivas-Martínez S. 2008. Global bioclimatics (Clasificación biclimática de la Tierra) (versión 01-12-2008). Available at: http://www.globalbioclimatics.org (last access 19-08-2011).

Rivas-Martínez S, Fernández-Gonzáles F, Loidi J. 1999. Checklist of plant communities of Iberian Peninsula, Balearic and Canary Islands to suballiance level. Itinera Geobotanica, 13: 353-451.

Shi S, Gu JX. 2007. Ecohydrological functions of litter in three main plant communities on Songen grassland. Chinese Journal of Applied Ecology, 18: 1722-1726.

ter Braak CJF, Smilauer P. 2002. CANOCO Reference Manual and CanoDraw for Windows User's Guide: Software for Canonical Community Ordination (version 4.5). Ithaca NY, USA, Microcomputer Power.

Tutin TG, Heywood VH, Burges NA, Chater AO, Edmonson JR, Heywood VH, Moore DM, Valentine DH, Walters SM, Webb DA. (eds). 1993. Flora Europaea. Ed. 2, Vol. 1, Cambridge, London, New York, Melbourne: Cambridge University Press.

Tutin TG, Heywood VH, Burges NA, Valentine DH, Walters SM, Webb DA. (eds.) et Coll., 1964-1980. Flora Europaea. Cambridge, London, New York, Melbourne: Cambridge University Press,

van der Maarel E. 1979. Transformation of cover-abundance values in phytosociology and its effect on community similarity. Vegetatio, 39: 97-114.

Verdaguer D, Sala A, Vilà M. 2010. Effect of environmental factors and bulb mass on the invasive geophyte Oxalis pes-caprae development. Acta Oecologica, 36: 92-99. 


\section{Appendix I. Raw data of sample site}

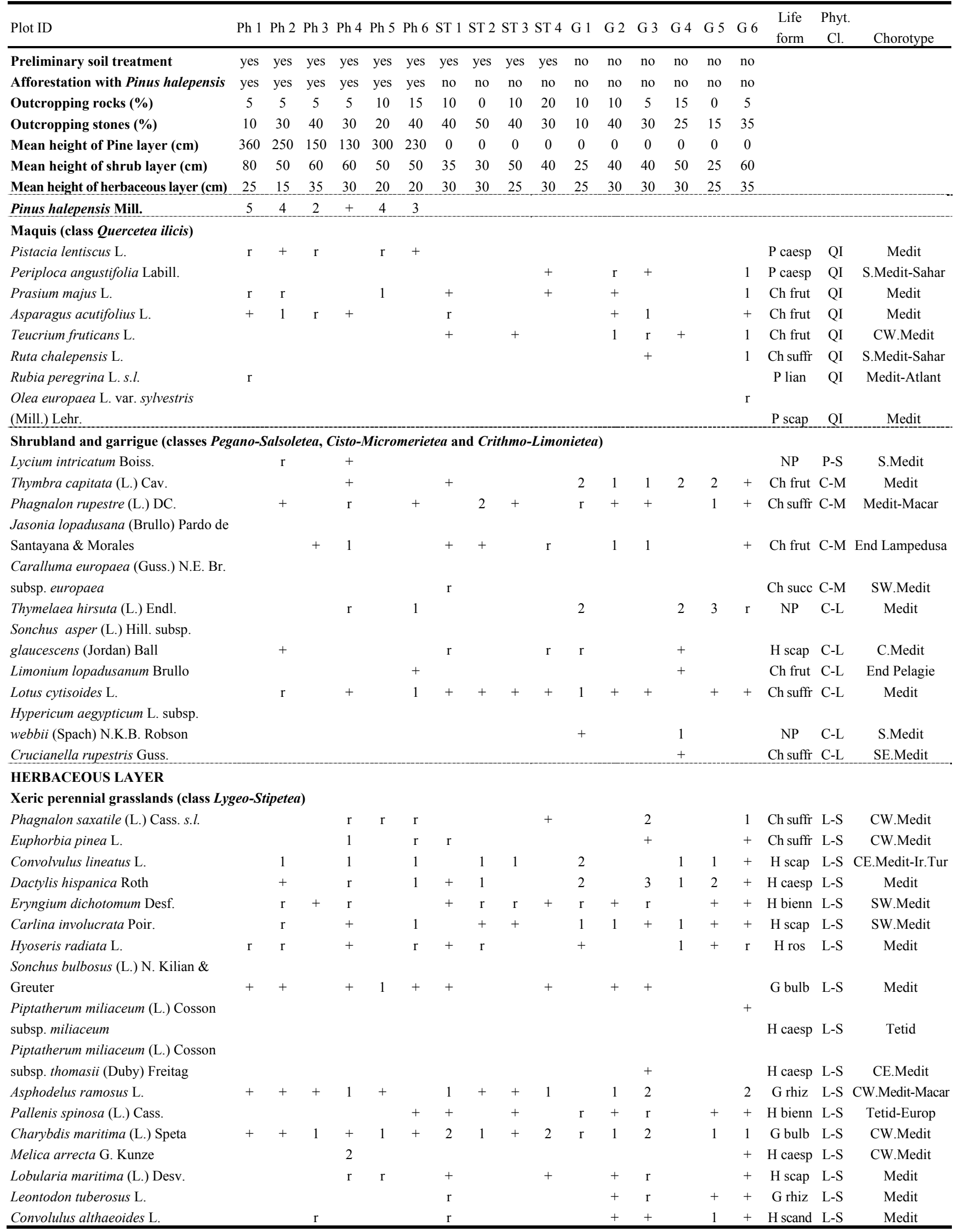




\section{Continue Appendix I}

\begin{tabular}{|c|c|c|c|c|c|c|c|c|c|c|c|c|c|c|c|c|c|c|c|}
\hline Plot ID & $\mathrm{Ph} 1$ & $\mathrm{Ph} 2$ & $\mathrm{Ph} 3$ & $\mathrm{Ph} 4$ & $\mathrm{Ph} 5$ & $\mathrm{Ph} 6$ & ST 1 & ST 2 & ST 3 & ST 4 & G 1 & G 2 & G 3 & G 4 & G 5 & G 6 & $\begin{array}{l}\text { Life } \\
\text { form }\end{array}$ & $\begin{array}{l}\text { Phyt } \\
\text {. Cl. }\end{array}$ & Chorotype \\
\hline Allium roseum $\mathrm{L}$. & & & & & + & & & & & 1 & & & + & & + & + & G bulb & L-S & Medit \\
\hline Thapsia pelagica Brullo, Guglielmo, & & & & & & & & & & & & & & & & + & & & \\
\hline Pasta, Pavone \& Salmeri & + & + & + & + & + & $\mathrm{r}$ & 1 & 1 & + & 1 & $\mathrm{r}$ & 1 & 1 & + & & & H scap & L-S & End Lampedusa \\
\hline Allium pallens $\mathrm{L}$. & & & + & $\mathrm{r}$ & & & & & & & & + & & & & + & G bulb & L-S & Medit \\
\hline Reichardia picroides (L.) Roth & & + & & & & & + & + & & + & $\mathrm{r}$ & + & + & + & + & + & H scap & L-S & Medit \\
\hline Ophrys ciliata Biv. & & & & & & & & $\mathrm{r}$ & & & & $\mathrm{r}$ & & & & & G bulb & L-S & Medit \\
\hline Lathyrus clymenum $\mathrm{L}$. & & & & & + & & & & & & & & & & & & T scap & L-S & Medit \\
\hline Foeniculum vulgare Mill. subsp. vulgare & & & & & & & & & & + & & & & & & & H scap & L-S & Medit-Ir.Tur \\
\hline Hyparrhenia hirta (L.) Stapf s.l. & & & & & & & & & & & & & & & & + & H caesp & L-S & Tetid-Paleotrop \\
\hline Poa bulbosa L. & & & & & & & & & & & & & & & & + & H caesp & L-S & Tetid-Eurosib \\
\hline \multicolumn{20}{|c|}{ Ephemeral prairies (classes Stipo-Trachynietea distachyae and Saginetea maritimae) } \\
\hline Trachynia distachya (L.) Link & & + & 1 & 1 & + & 2 & & & 3 & + & 1 & & & + & + & + & T scap & S-TD & Tetid \\
\hline Reichardia tingitana (L.) Roth & & + & & 1 & & + & & & + & & & & & & & & T scap & S-TD & Tetid \\
\hline Scorpiurus muricatus L. s.l. & & + & 1 & $\mathrm{r}$ & & + & + & + & & $\mathrm{r}$ & & & + & $\mathrm{r}$ & + & + & T scap & S-TD & Medit \\
\hline Linum trigynum $\mathrm{L}$. & & & & + & & & + & & + & & & & $\mathrm{r}$ & & & + & T scap & S-TD & Tetid-Europ \\
\hline Linum strictum L. s.l. & & & + & & & + & & + & & $\mathrm{r}$ & + & & + & + & + & + & T scap & S-TD & Medit \\
\hline Salvia verbenaca L. s.l. & & $\mathrm{r}$ & & & & $\mathrm{r}$ & $\mathrm{r}$ & & & & & + & & & & + & H bienn & S-TD & Medit-Atlant \\
\hline \multicolumn{20}{|l|}{ Plantago afra L. subsp. zwierleinii } \\
\hline (Nicotra) Brullo & & + & 1 & 1 & & & & 1 & & + & & $\mathrm{r}$ & & & & & H scap & S-TD & End Sicily \\
\hline Diplotaxis scaposa DC. & & + & & + & & & + & & & & & + & $\mathrm{r}$ & & & & T scap & S-TD & End Lampedusa \\
\hline Daucus siculus Tineo & & & & + & & & & & & & & + & $\mathrm{r}$ & & + & $\mathrm{r}$ & H bienn & S-TD & End S.Italy \& Sicily \\
\hline \multicolumn{20}{|l|}{ Linaria reflexa (L.) Desf. subsp. } \\
\hline lubbockii (Batt.) Brullo & & & & + & & & $\mathrm{r}$ & + & & & & & & & & & T rept & S-TD & S.Medit \\
\hline Hypochoeris achyrophorus L. & $\mathrm{r}$ & + & 1 & + & & & + & 1 & & + & & + & 1 & + & + & + & $\mathrm{T}$ ros & S-TD & Medit \\
\hline \multicolumn{20}{|l|}{ Euphorbia pycnophylla (K.U. Kramer } \\
\hline \& Westra) C. Brullo \& Brullo & & + & + & $\mathrm{r}$ & & & & + & & + & + & & $\mathrm{r}$ & + & + & & T scap & S-TD & End Lampedusa \\
\hline Sideritis romana $\mathrm{L}$. & & & & $\mathrm{r}$ & & & & + & $\mathrm{r}$ & $\mathrm{r}$ & & & + & & & & T scap & S-TD & Medit \\
\hline Tordylium apulum $\mathrm{L}$. & & + & + & & $\mathrm{r}$ & & + & 1 & & + & & & + & & & + & T scap & S-TD & Medit-Europ \\
\hline Filago pygmaea $\mathrm{L}$. & & & $\mathrm{r}$ & & & & & + & & & & & & & & & T rept & S-TD & Medit-Macar \\
\hline Senecio leucanthemifolius Poir. s.l. & & & & + & & & + & & & + & & & & & & & T scap & S-TD & CW.Medit \\
\hline Tripodion tetraphyllum (L.) Fourr. & & & + & & & & & & & $\mathrm{r}$ & & & $\mathrm{r}$ & & & $\mathrm{r}$ & T scap & S-TD & Medit \\
\hline Hedypnois rhagadioloides (L.) F.W. & & & & & & & & & & & & & & & & + & & & \\
\hline Schmidt & & & + & & + & & $\mathrm{r}$ & & & + & + & & & & & & $\mathrm{T}$ ros & S-TD & Medit-Ir.Tur \\
\hline Lagurus ovatus L. subsp. nanus & & & + & & & & & + & & $\mathrm{r}$ & & & & + & & & T scap & S-TD & CW.Medit \\
\hline Stipa capensis Thunb. & & & + & & & & & + & & & & & & & & & T scap & S-TD & Subcosmop \\
\hline Ononis reclinata $\mathrm{L}$. & & & & & & & & & & & $\mathrm{r}$ & $\mathrm{r}$ & $\mathrm{r}$ & & & & T scap & S-TD & Tetid-Atlant \\
\hline Centaurium pulchellum (Swartz) Druce & & & & & & & & & & & & & + & & & & T scap & S-TD & Olart \\
\hline Lotus edulis L. & + & & $\mathrm{r}$ & & & & & + & & & & & + & & + & & T scap & S-TD & Medit \\
\hline Daucus lopadusanus Tineo & & $\mathrm{r}$ & & & & & & & & & 1 & + & & 1 & & & T scap & S-TD & End Lampedusa \\
\hline Filago gussonei Lojac. & & $\mathrm{r}$ & & & & & & & & + & & & & & & & T scap & S-TD & End S.Italy \& Sicily \\
\hline Ononis sieberi DC. & & + & & & & & + & & & & & & & & & & T scap & S-TD & CE.Medit \\
\hline Hyoseris scabra L. & & + & & & & & + & & & & & & & & & & $\mathrm{T}$ ros & S-TD & Medit \\
\hline Frankenia hirsuta $\mathrm{L}$. & & & & & & & & & & & & & & & & & Ch suffr & $\mathrm{SaM}$ & Medit-Pont \\
\hline Evax pygmaea (L.) Brot. & & & & & & & & & & & 1 & & & & + & & $\mathrm{T}$ ros & S-TD & Medit-Macar \\
\hline Anthemis lopadusana Lojac. & & & & & & & & & & & + & & & & & & T scap & $\mathrm{SaM}$ & End Lampedusa \\
\hline Asteriscus aquaticus (L.) Less. & & & & & & & & & & & & & & & & & T scap & SaM & Medit-Macar \\
\hline \multicolumn{20}{|c|}{ Nitrophilous-ruderal communities (classes Stellarietea mediae, Papaveretea rhoeadis and Onopordetea acanthii) } \\
\hline Avena barbata Link s.l. & & & 1 & + & + & & & + & + & + & & $\mathrm{r}$ & + & + & + & + & T scap & $\mathrm{SM}$ & Tetid-Pont \\
\hline Anagallis arvensis L. s.l. & & + & + & + & & & + & + & + & + & & + & + & & + & + & $\mathrm{T}$ rept & $\mathrm{SM}$ & Tetid-Europ \\
\hline Erodium malacoides (L.) L'Hérit. & & + & + & + & $\mathrm{r}$ & & + & + & & + & & & & & & & T scap & SM & Tetid \\
\hline Sonchus oleraceus L. & + & $\mathrm{r}$ & 1 & + & + & + & + & & & & & $\mathrm{r}$ & & + & + & $\mathrm{r}$ & T scap & SM & Bor-Tetid \\
\hline Oxalis pes-caprae L. & 1 & + & 1 & + & 3 & 1 & + & & & 1 & & & & & & & G bulb & $\mathrm{SM}$ & Introd \\
\hline \multicolumn{20}{|l|}{ Urospermum picroides (L.) F.W. } \\
\hline Schmidt & $\mathrm{r}$ & & + & + & $\mathrm{r}$ & & & & & & & & & & & & T scap & SM & Tetid \\
\hline Carduus argyroa Biv. & $\mathrm{r}$ & & + & $\mathrm{r}$ & & & & + & $\mathrm{r}$ & & & & & & & & T scap & SM & CW.Medit \\
\hline Galium verrucosum Schreber & & & & $\mathrm{r}$ & & & + & & & $\mathrm{r}$ & & & & & & & T scap & $\mathrm{SM}$ & Medit \\
\hline Echium plantagineum $\mathrm{L}$. & & & + & + & & & & $\mathrm{r}$ & $\mathrm{r}$ & & & & & & & + & H bienn & $\mathrm{SM}$ & Tetid-Europ \\
\hline Hippocrepis ciliata Willd. & & & & & & & & $\mathrm{r}$ & & & & & & & & & T scap & SM & Medit-Pont \\
\hline
\end{tabular}




\section{Continue Appendix I}

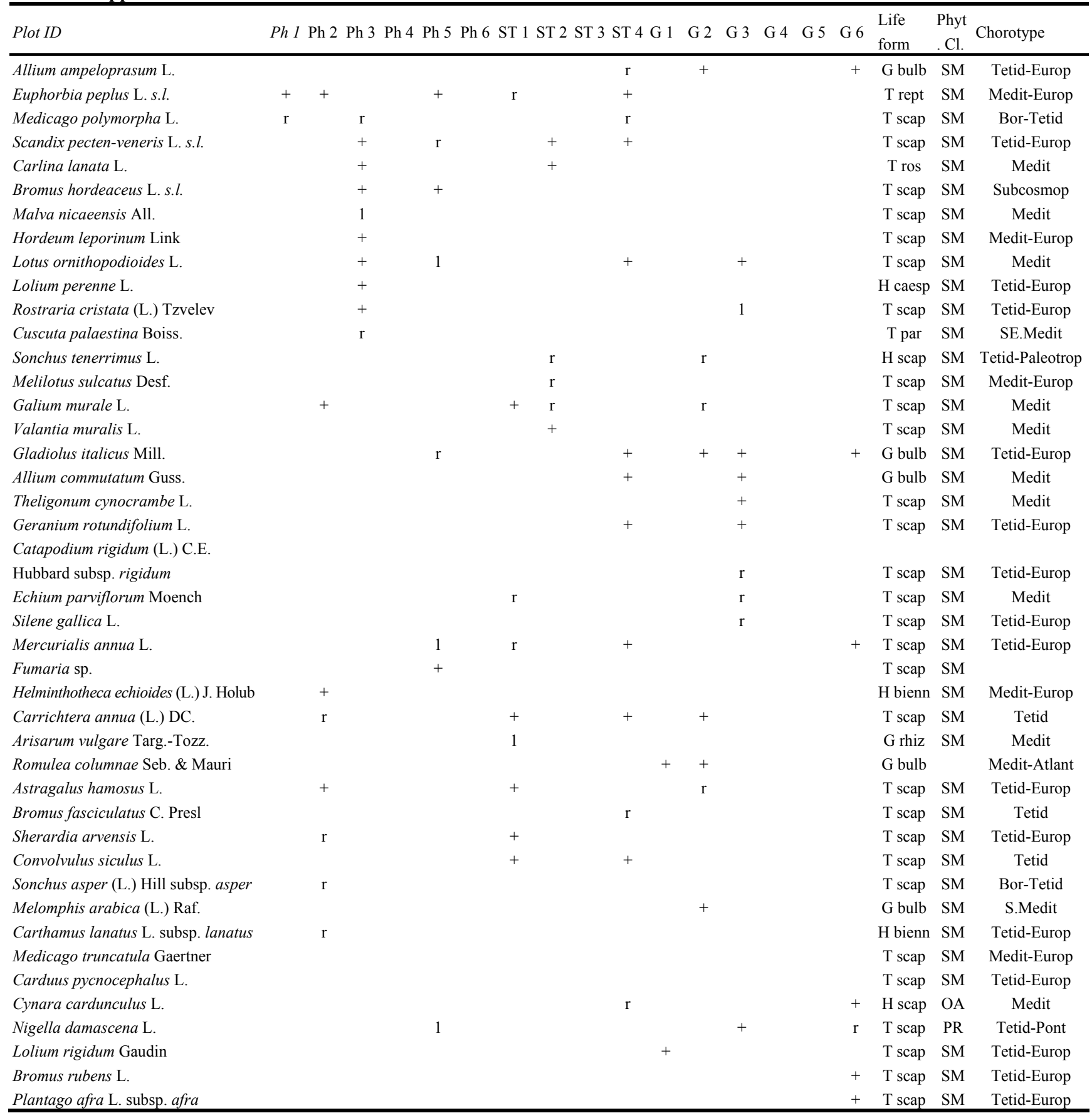

Life form: $\mathrm{P}=$ Phanerophyta, with three subcategories: scap = scaposa, caesp = caespitosa and lian = lianosa; NP = Nano-Phanerophyta; Ch $=$ Chamaephyta, with three subcategories: frut $=$ fruticosa $($ shrubs), suffr $=$ suffruticosa (subshrubs) ans succ $=$ succulenta (succulents); $\mathrm{H}=$ Hemicryptophyta, with five subcategories: scap $=$ scaposa, caesp $=$ caespitosa, bienn $=$ biennia, scand $=$ scandentia and $\operatorname{ros}=$ rosulata; $\mathrm{G}=$ Geophyta, with two subcategories: rhiz $=$ rhizomatosa and bulb $=$ bulbosa; $\mathrm{T}=$ Therophyta, with four subcategories: $\mathrm{scap}=$ scaposa, rept $=$ reptantia, $\operatorname{ros}=$ rosulata and par $=$ parasytica. Phytosociological class: $\mathrm{C}-\mathrm{L}=$ CrithmoLimonietea $; \mathrm{C}-\mathrm{M}=$ Cisto-Micromerietea $; \mathrm{L}-\mathrm{S}:$ Lygeo-Stipetea $; \mathrm{OA}=$ Onopordetea acanthii $; \mathrm{PR}=$ Papaveretea rhoeadis; $\mathrm{P}-\mathrm{S}=$ Pegano-Salsoletea $; \mathrm{QI}=$ Quercetea ilicis; $\mathrm{SaM}=$ Saginetea maritimae; $\mathrm{SM}=$ Stellarietea mediae; $\mathrm{S}-\mathrm{TD}=$ Stipo-Trachynietea distachyae. Chorotype: $(\mathrm{CW})$ Medit-Macar $=(\mathrm{CW}) \mathrm{Mediterranean-}$ Macaronesian; (S, SW, SE, C, CW, CE) Medit = (S, SW, SE, C, CW, CE) Mediterranean; Bor-Tetid = Borea-Tethisian; $(\mathrm{CE})$ Medit-Ir.Tur $=(\mathrm{CE})$ MediterraneanIrano-Turanian; End = endemic; Introd = introduced; Medit-Atlant = Mediterranean-Atlantic; Medit-Europ = Mediterranean-European; Medit-Pont = Mediterranean-Pontian; Olart $=$ Holarctic; S.Medit-Sahar $=$ S Mediterranean-Saharian; Subcosmop $=$ Subcosmopolitan; Tetid $=$ Tethisian; Tetid-Atlant $=$ TethisianAtlantic; Tetid-Europ $=$ Tethisian-European; Tetid-Eurosib $=$ Tethisian-Eurosiberian; Tetid-Paleotrop $=$ Tethisian-Palaeotropical 